\title{
Determinants of Household Savings: An Empirical Evidence from the OECD Member Countries
}

\author{
Ethan Hunt \\ First Guaranty Bank, Hammond, Louisiana 70401, USA \\ Tel: 1-318-816-3798Ｅ-mail: huntethan46@yahoo.com
}

Dr. Hyungjoon Jeon

Department of Taxation Science, Changwon National University

Changwon-si, Gyeongsangnam-do, 51140, South Korea

Tel: 82-55-213-33705 E-mail: jeon266@changwon.ac.kr

\author{
Dr. Sang Lee \\ Department of Management and Business Administration \\ Southeastern Louisiana University, SLU 10813, Hammond, LA 70402, USA \\ Tel: 1-985-549-2086Ｅ-mail: slee@ southeastern.edu
}

Received: March 3, 2021 Accepted: March 18, 2021 Published: March 25, 2021

doi:10.5296/ber.v11i2.18369 URL: https://doi.org/10.5296/ber.v11i2.18369

\begin{abstract}
Using the data from the 36 OECD member countries over a time period of 1970-2017, we study variations in household saving rate across the countries through the lens of the socio-economic and -demographic shifts over time. In addition to traditional determinants of household saving such as life expectancy, education, average number of children born per woman over a lifetime, and household debts, we examined changes in the socio-economic and -demographic conditions that are conducive to the human capital value of female labor force and thus female employment opportunities. We have identified that the narrower is the gap between genders in higher education attainment and employment, the higher is the household saving rate. Our empirical findings also suggest that both giving childbirth at an old age and preferential income tax rates for households with children are negatively
\end{abstract}


affecting the household saving rate.

Keywords: Household saving rate, Gender gap, Labor force, Childbirth

\section{Introduction}

Saving, commonly defined as unspent income set aside for future consumption or investment, is important at all levels of economic activity. And it is even more essential for the whole economy not only because saving is a potential source of sustained increases in technology and capital growth, ultimately leading to economic growth, but also because a structural change or shift in household or personal saving behavior would have implications of much significance for future economic growth and financial market stability (Ouliaris and Rochon, 2018). Although there is much consensus on the role of aggregate saving in the economy as a whole such as the accumulation of productive capital and a sustained increase in productivity, primary decision factors of saving at household level are far from agreed upon as households are heterogeneous in many aspects (Beckmann et al., 2013). In the literature of household saving behavior, much has been written about a long-run relationship between household savings rate and both internal and external factors that are deemed relevant to household saving (Friedman, 1957; Ando \& Modigliani, 1963; Feldstein, 1974 \& 1982; Diamond \& Hausman, 1984; Hubbard, 1986; Poterba, 1994 \& 1996; Harrigan, 1996; Masson et al., 1998; Joo \& Grable, 2000; Browning \& Crossley, 2001; Gourinchas \& Parker, 2002; Harris et al., 2002; Carroll et al., 2003; Ozcan et al., 2003; Case et al., 2005; Dvornak \& Kohler, 2007; Kim, 2010; Beckmann et al.,2013; Roche et al., 2013; Summers, 2016). However, the question as to what determines household or personal saving is still not a fully resolved issue.

One of the central questions regarding the household saving behavior is declining trends in household saving rate across countries. For instance, the U.S. household saving rate was above 10 percent until 1980 but has dropped to a single digit since 1985. According to the OECD Family Data Base, the U.S. household saving rate amounted only to 6.89 percent in 2017. More or less the same trend is observed among the member countries of the Organization for Economic Cooperation and Development (OECD). The average household saving rate of the OECD member countries was about 13.40 percent in the 1970 s, 9.28 percent in the 1980s, and 6.17 percent in the 1990s. Since 2000, the average household saving rate has been as low as about 4.5 percent.

Another issue of central importance is significant variations in household saving rate across countries. For instance, the household saving rates in 2017 among the OECD member countries varied from the lowest of -16.91 percent in Greece to 16.10 percent in Luxemburg as the highest. Such widespread variations in household saving rate are consistently observed over time among the OECD member countries. For example, in 2000, Latvia's household saving rate was about -9.79 percent while that of Switzerland was almost 14 percent.

Understanding what underlies household saving behavior requires both theoretical and empirical investigations into a complex linkage between household saving behavior and all potential contributing factors, which encompass a wide range of saving motives, sociodemographic characteristics, changes in economic environments and social norms, 
life-time income profiles, institutional or regulatory legacies of social insurances, and so forth. Most conventional studies of saving behavior in the literature have adopted their theoretical framework that draw from the prominent saving behavior models such as life-cycle models, precautionary saving models, or bequest models.

Departing from such traditional conceptual framework, this study aims to investigate the two stylized facts about household saving - a declining trend as well as wide differences in household saving rate across countries - with specific emphasis on female socio-economic and -demographic changes in comparison with male. Using the data from the OECD Family Database and the OECD Database over a time period 1970-2017, we attempt to explain wide variations in household saving rates among the OECD member countries primarily through the lens of the socio-economic and -demographic shifts over time that may be more conducive to narrowing the gender gap in income profiles, for instance, such as female employment opportunities and the human capital potential of female labor force.

The rest of this study is organized as follows. In Section 2, we briefly review three prominent hypotheses of saving and then introduce control variables of interest along with principal empirical findings in the literature. In Section 3, the data source and empirical strategy for our study are elaborated. Our empirical specification and results are discussed in Section 4, followed by the concluding remarks in Section 5.

\section{Literature Review}

\subsection{Three Prominent Models of Saving Behavior}

The study of saving and consumption decisions at personal or household level has evolved centered on the three prominent hypotheses: the life-cycle hypothesis, the precautionary saving hypothesis, and the bequest motive hypothesis. The life-cycle hypothesis, which is the earliest standard saving decision model, presumes that people save mainly for future consumption. Individuals try to stabilize or smooth consumption over their lifetime by saving a portion of income or accumulating financial resources during high-income periods and borrowing from their savings or decumulating assets during low- or no-income periods (Ando \& Modigliani, 1963). This model is noted for its prediction of an age-specific pattern of saving known as a hump-shaped income-age profile (Poterba, 1996; Beckmann et al., 2013). Another theory of saving that is closely related to the life-cycle hypothesis is the permanent income hypothesis (Friedman, 1957). The two dominant theories of saving behavior are similar in that they both assume that individuals are logical or rational in making decisions about present and future consumption (Sawsdpeera \& Pandey, 2012). However, the life-cycle hypothesis has largely failed to fit the existing household data and the empirical findings were hardly reconciled with a hump-shaped income-age profile predicted by the life-cycle hypothesis (Poterba, 1994 \& 1996; Banks et al., 1998; Mulligan, 2014). For instance, Poterba (1994) reports in his study of six OECD countries relatively high positive personal saving rates even after retirement. In the study, households aged 65-69 exhibited a saving rate of 36 percent in Italy and 32 percent in Japan. In addition, a significant variation in saving rate was observed across the six countries. For households aged 50-54, a saving rate varied from the lowest of 8 percent in Canada to 31.5 percent in Japan as the highest. 


\section{MInstitute ${ }^{\text {Mech }}$}

Business and Economic Research ISSN 2162-4860 2021, Vol. 11, No. 2

Since Leland (1968) incorporated uncertainty into an intertemporal saving model, precautionary saving motive has long been recognized as an alternative to the life-cycle hypothesis (Kimball, 1992; Weil, 1993; Cagetti, 2000; Menegatti, 2007; Nocetti \& Smith, 2011; Magnani, 2017; Vergara, 2017). With the presumption that there is a link between income uncertainty and the level of dissaving (Carroll, 1992), the precautionary saving hypothesis captures the effects of future income uncertainty on intertemporal wealth allocation (Baiardi et al., 2019). However, empirical testing or investigations of precautionary saving hypothesis have still remained a challenging task due to the conceptual issues associated with the measurement of wealth and risk (Kennickell \& Lusardi, 2004). As a result, empirical evidence of precautionary saving in household wealth accumulation is mixed and the magnitude of the estimates of precautionary saving instruments varies to a large degree, ranging from being little to modest to sizable (Skinner, 1988; Hubbard et al., 1995; Lusardi, 1997 \& 1998; Carroll \& Samwick, 1997), implying that household saving decisions under precautionary motives are highly susceptible to changes in economic and welfare environments such as social safety net programs (Poterba, 1996).

Bequest motives, another alternative to the life-cycle hypothesis, have also been proposed as an important driver of saving decision in the literature of saving behavior. In the simple life-cycle hypothesis where no precautionary or bequest motives for saving are present, it is presumed that an individual's primary saving motive is to smooth or spread her consumption over her lifetime. However, such predictions are rarely borne out in real life as most people possess or leave behind non-trivial amount of assets at the time of their death. In other words, as the simple life-cycle hypothesis fails to explain why people after retirement are saving more than is necessary, bequest motives have been accepted as an explanation for the phenomenon of a relatively large fall in consumption after retirement. It is conceivable that leaving bequests to heirs or a charity is positively associated with an increase in satisfaction or utility of a bequest giver (Barro, 1974). As Poterba (1996) argues, bequeathing is a realistic motive for saving and a substantial portion of an individual's lifetime saving is for bequest purposes. Yet there is no consensus as to the socio-economic factors that influence or contribute to bequest motives. Nor is much known about the significance of bequest motives in saving decisions relative to precautionary saving motives. For instance, dollars saved today for precautionary purposes could be used for bequests if no random events occur (Dynan et al., 2002). Similar to the issues of measuring wealth and risk in precautionary saving models, empirical testing of bequest motives in saving decisions remains difficult as bequest and precautionary saving motives are not easily identifiable (Poterba, 1996; Ameriks et al., 2011; De Nardi et al., 2015).

\subsection{Internal and External Determinants of Saving}

In the literature of saving decisions, various factors have been examined to identify saving motives. Some of the common variables include age, often age squared also, of a household head, gender, marital status, household income, education, status of employment, the presence of children and/or old dependents, credit outstanding, real estate loans, statutory saving imposition, real interest rates, and so on. 
Among internal factors, a household head's age and the number of children in the household are typically controlled for in the standard empirical estimation of the life-cycle hypothesis. Age is expected to have a positive impact on private saving at a decreasing rate (Ameriks \& Zeldes, 2004; Swasdpeera \& Pandey, 2012; Beckmann et al., 2013) while the effect of the presence of young dependency on saving is mixed in the literature (Joo \& Grable, 2000; Athukorala \& Tsai, 2003; Swasdpeera \& Pandey, 2012). The level or growth rate of household income appears to have a positive impact on personal or household saving (Harrigan, 1996; Poterba \& Wise, 1996; Joo \& Grable, 2000; Harris et al., 2002; Ozcan et al., 2003). Gender does not appear to have a significant impact on personal saving ratio or saving amount (Swasdpeera \& Pandey, 2012; Beckmann et al., 2013). Tertiary or higher education appears to be conducive to private saving (Poterba \& Wise, 1996; Joo \& Grable, 2000; Unny, 2002; Swasdpeera \& Pandey, 2012; Beckmann et al., 2013).

Among external factors, real interest rates, statutory saving imposition, and the growth of per capita Gross Domestic Product (GDP) have been frequently examined in the literature as a potential determinant of private saving. Real interest rate is a variable of interest in the precautionary saving hypothesis. The effect of real interest rate on private saving in the literature is mixed. Masson et al. (1998), Athukorala and Sen (2001), Pootrakool et al. (2005), and Ouliaris and Rochon (2018) reported a positive effect of real interest rate on private saving while Kim (2010) showed an indeterminate outcome. The net saving effect on private saving of statutory saving imposition such as the Social Security program has also been an area of interest in the literature, but empirical results are limited and mixed (Hubbard, 1986; Poterba, 1996; Harrigan, 1996; Kim, 2010).

\section{Data, Variables, and Empirical Strategy}

This study aims to explain variations in the household saving rate among the 36 OECD member countries through the lens of the gender gap in the socio-economic and -demographic conditions. All socio-economic and -demographic sample observations are from the OECD Family Database (http://www.oecd.org/els/family/database.htm) and the OECD Data (https://data.oecd.org) over a time period of 1970-2017. The 36 OECD member countries represent Asia, Europe, Central America and North America and exhibit variations in cultural value as well as socio-economic and -demographic diversity. The data used for regressions in this study is an unbalanced panel. As the descriptive statistics in Table 1 shows, actual number of observations varies across variables. Some basic demographic information like fertility rate and life expectancy at birth has more than 1,300 observations while some economic indicators at household level have observations fewer than 800 .

The dependent variable, household saving rate, is defined as the total amount of net saving as a percentage of net household disposable income. Our explanatory variables include several measures of socio-economic and -demographic conditions that are conducive to female employment prospects and the human capital of female labor force. The variable, total fertility rate, is defined as the average number of children born per woman over a lifetime given current age-specific fertility rates. Although this variable is measured at the average level of a country rather than at the household level, we expect this variable to capture the 
effects of the presence of children on the household saving rate in more than one way. First, the presence of financially dependent children will shift household expenditures upward and thus is likely to reduce household saving rate. Second, the presence of children may limit the income profiles of female by the extent to which female employment prospects are compromised by the presence of dependents. As low household income is strongly associated with low household saving, lower income profiles of female associated with a higher fertility rate may reduce household saving rate.

Table 1. Descriptive statistics

\begin{tabular}{|l|l|l|l|l|l|}
\hline Variable & Observations & Mean & Std. Dev. & Min & Max \\
\hline fertility rate & 1332 & 1.772 & .478 & 1.05 & 4.64 \\
\hline adult higher education & 789 & 27.563 & 10.926 & 4.758 & 57.888 \\
\hline life expectancy & 1368 & 76.404 & 4.015 & 58.667 & 84.1 \\
\hline gender gap in higher education & 775 & -1.886 & 7.122 & -20.317 & 20.655 \\
\hline gender gap in employment & 990 & 15.534 & 10.046 & -2 & 50 \\
\hline household debt & 708 & 109.758 & 65.316 & 2.711 & 339.778 \\
\hline household disposable income growth rate & 816 & 2.45 & 3.022 & -12.783 & 22.232 \\
\hline household net worth & 614 & 387.209 & 114.424 & 106.946 & 710.921 \\
\hline household saving rate & 807 & 5.494 & 6.457 & -40.312 & 20.537 \\
\hline mean age of woman at childbirth & 912 & 29.215 & 1.489 & 24.7 & 32.6 \\
\hline income tax rate differential & 684 & 2.305 & 2.965 & -3.4 & 12.3 \\
\hline
\end{tabular}

Note. OECD Family Database (http://www.oecd.org/els/family/database.htm) and OECD Database (https://data.oecd.org/).

We consider another fertility-related indicator, the mean age of woman at childbirth. This variable is calculated as the simple mean average age in years of women at childbirth. We expect this indicator to be negatively correlated with household income and thus household saving. Our economic reasoning is that giving birth at a relatively high mean age may cause mid-career interruptions for women and diminish the human capital of adult female labor force, leading to lower household incomes and thus lower household savings.

To examine the effect of household income profiles on household saving rate conditional on higher education attainment, we use two different measures of adult education at tertiary level. First, we look at the share of the 25-64 year-old population which completed tertiary education. The attainment of higher education is a strong indicator of high household income and saving in the literature. Second, we pay added attention to educational gender gap in tertiary education for the 25-64 year-old population. The variable is measured as the difference in the attainment rate of higher education between 25-64 year-old male population and female population. The educational gender gap in tertiary education is expected to be negatively correlated with household saving rate because we believe a smaller educational gender gap is more conducive to higher household income and thus higher household saving.

It's been known that female labor force participation follows a U-shape because economic development leads to an increase in female education and the growth of service sector for which female labor force has a comparative advantage (Durand, 1979; Jayachandran, 2020). In light of this, we control for a gender gap in employment. The variable is defined as 
male-less-female in the employment-to-population rate. We expect the gender gap in employment to be negatively correlated with the dependent variable in that the smaller gender gap in employment, the higher is female income profiles and thus household income as well as saving.

We also control for life expectancy at birth and average personal income tax rate differential between households with no children and households with two children. The variable, life expectancy at birth, is expected to have a positive impact on household saving rate because a greater portion of income needs to be saved to spread consumption over a longer lifetime as predicted by the life-cycle hypothesis. The variable, average personal income tax rate differential, is expected to be negatively correlated with household saving rate. The economic reasoning is that the greater is the differential, the greater is an economic incentive to have more children, and the lower is the household saving rate.

Finally, we consider three potential determinants of household saving rates that are associated with precautionary saving motives: household debt, household net worth, and the growth rate of disposable household income. According to the OECD Data, household debt is defined as all liabilities of households that require payments of interest or principal and is measured as a percentage of net household disposable income. The variable, household net worth, is measured as a percentage of household net disposable income. We expect all three variables to be negatively correlated with household saving rate.

\section{Empirical Model Specification and Estimation Results}

We fit a fixed effects model on the unbalanced panel data discussed in the previous section. The use of a fixed effects model is based on the following assumptions. First, it is presumed that each sample country has its own individual characteristics that are time invariant within a sample country but may affect the dependent variable household saving rate. Country-specific time-invariant characteristics may include gender-specific cultural norms such as female employment opportunities, household size, demographic composition, social insurance programs, income tax systems, educational opportunities, and so on. In the literature of cross-sectional time series, such country-specific time-invariant factors are controlled for by fitting a fixed effects model. Thus, our fixed effects model is fitted as follows:

$$
y_{i t}=\boldsymbol{x} \boldsymbol{\beta}+\alpha_{i}+\mu_{i t}
$$

where

$$
\begin{aligned}
& y_{i t}=\text { the dependent variable (divorce rate) of a sample country } i \text { at year } t, \\
& \boldsymbol{x}=\text { a vector of the explanatory variables }\left(x_{i t}\right), \\
& \alpha_{i}=\text { the unknown intercept for each sample country }(i=1 \cdots 36), \\
& \mu_{i t}=\text { the error term. }
\end{aligned}
$$

Table 2 reports the fixed effects regression results of three models using the de-meaned data. The Hausman specification test statistics rejects the null hypothesis of a random effect 
estimation and support the presumption of country-specific time-invariant factors. In each model, standard errors are reported in the parenthesis along with the statistical significance of each estimated coefficient. The empirical specification is the same except the last three explanatory variables: household debt, household net worth, and household disposable income growth rate. We controlled for these three variables separately mainly because they were highly correlated with each other. First, the mean age of woman at childbirth is a strong indicator of a change in household saving rate. Its estimated coefficients are statistically significant and negative in all three models. It may be inferred that a woman giving childbirth at an old age is more likely to be at or near her mid-career and choosing children over a career may reduce her personal or household income and thus saving. It is a finding of interest that the fertility rate, the average number of children born per woman over a lifetime, is not a statistically significant factor in household saving decisions.

The variable, life expectancy, is positively correlated with household saving rate and is in support of the life-cycle hypothesis of saving. All estimated coefficients are positive and statistically significant. Another interesting empirical finding is gender gap in employment which is calculated as the percentage point difference between the male employment rate and the female employment rate for the 25-64 year-old population. Although gender gap in employment is not necessarily indicative of gender gap in pay, a smaller gender gap in employment suggests female income profiles are close to male income profiles and thus higher household saving rate is likely to be higher.

We look into personal income tax rates by family type and control for the income tax rate differential between one-earner married couple without children and with two children. The estimated coefficients are all negative and statistically significant. The finding is consistent with our underlying presumption that a special tax treatment to married individuals or families with children could be conducive to an increase in the family or household size. It is conceivable that the presence of dependents shifts household spending more than it reduces income tax liability, causing a fall in the household saving rate.

The estimated coefficients of household debt, household net worth, and household disposable income growth rate are all negative as predicted, but none of them appear to play a significant role in household saving behavior or decisions. 
Table 2. Regression results

\begin{tabular}{|l|l|l|l|}
\hline household saving rate (dep. var.) & $(1)$ & $(2)$ & $(3)$ \\
\hline fertility rate & 2.436 & .844 & 1.633 \\
\hline & $(1.841)$ & $(1.899)$ & $(1.813)$ \\
\hline mean age of woman at childbirth & $-2.814^{* * *}$ & $-2.282^{* * *}$ & $-2.856^{* * *}$ \\
\hline & $(.698)$ & $(.748)$ & $(.688)$ \\
\hline adult higher education & -.043 & -.102 & -.033 \\
\hline & $(.084)$ & $(.091)$ & $(.084)$ \\
\hline life expectancy & $1.996^{* * *}$ & $1.98^{* * *}$ & $1.874 * *$ \\
\hline & $(.351)$ & $(.353)$ & $(.343)$ \\
\hline gender gap in employment & $.24 * * *$ & $.378 * * *$ & $.249 * * *$ \\
\hline & $(.072)$ & $(.095)$ & $(.076)$ \\
\hline income tax rate differential & $-.307^{* *}$ & $-.37 * * *$ & $-.29 * *$ \\
\hline & $(.127)$ & $(.133)$ & $(.128)$ \\
\hline household debt & -.013 & & \\
\hline & $(.01)$ & & \\
\hline household net worth & & -.005 & \\
\hline & & $(.005)$ & \\
\hline household disposable income gr. & & & -.031 \\
\hline & & & $(.064)$ \\
\hline constant & $-72.199 * * *$ & $-83.597 * * *$ & $-62.144 * * *$ \\
\hline & $(19.712)$ & $(20.835)$ & $(19.673)$ \\
\hline Observations & 475 & 414 & 481 \\
\hline R-squared & .138 & .153 & .161 \\
\hline F-statistics & $\mathrm{F}(7,438)=6.07$ & $\mathrm{~F}(7,381)=6.92$ & $\mathrm{~F}(7,444)=5.65$ \\
\hline
\end{tabular}

Note. Standard errors are in parenthesis. ***, **, and * indicate statistical significance at 1,5 , and 10 percent level, respectively.

In the literature, the level of income, income deciles, and income growth have been shown positively related to household saving (Harrigan, 1996; Harris et al., 2002; Ozcan et al., 2003). Since income profiles are highly correlated with education, it is a reasonable economic inference that a larger share of adult population with education at tertiary level leads to a higher saving. On the contrary, the regression results in Table 2 show that the effect of adult higher education on household saving rate is indeterminate with the estimated coefficient sign opposite to our prediction. 
Table 3. Regression results with gender gap in higher education

\begin{tabular}{|l|l|l|l|}
\hline household saving rate (dep. var.) & $(1)$ & $(2)$ & $(3)$ \\
\hline fertility rate & 2.125 & .388 & 1.226 \\
\hline & $(1.82)$ & $(1.915)$ & $(1.806)$ \\
\hline mean age of woman at childbirth & $-3.422^{* * *}$ & $-2.982^{* * *}$ & $-3.36^{* * *}$ \\
\hline & $(.674)$ & $(.719)$ & $(.668)$ \\
\hline gender gap in higher education & $-.233^{*}$ & $-.274^{*}$ & $-.233^{*}$ \\
\hline & $(.137)$ & $(.154)$ & $(.136)$ \\
\hline life expectancy & $1.8^{* * *}$ & $1.619^{* * *}$ & $1.638^{* * *}$ \\
\hline gender gap in employment & $(.344)$ & $(.352)$ & $(.333)$ \\
\hline & $.228^{* * *}$ & $.343^{* * *}$ & $.249^{* * *}$ \\
\hline income tax rate differential & $(.07)$ & $(.092)$ & $(.073)$ \\
\hline & $-.304^{* *}$ & $-.378^{* * *}$ & $-.283^{* *}$ \\
\hline household debt & $(.125)$ & $(.135)$ & $(.126)$ \\
\hline & $-.018^{*}$ & & \\
\hline household net worth & $(.01)$ & & \\
\hline & & $-.011^{* *}$ & \\
\hline household disposable income gr. & & $(.005)$ & \\
\hline & & & -.038 \\
\hline constant & $-39.284^{* *}$ & $-34.912^{*}$ & $(.061)$ \\
\hline & $(19.684)$ & $(21.094)$ & $(19.302)$ \\
\hline Observations & 488 & 426 & 494 \\
\hline R-squared & .105 & .082 & .153 \\
\hline F-statistics & $\mathrm{F}(7,450)=6.24$ & $\mathrm{~F}(7,392)=6.59$ & $\mathrm{~F}(7,456)=5.83$ \\
\hline
\end{tabular}

Note. Standard errors are in parenthesis. $*^{* *}, *^{*}$, and $*$ indicate statistical significance at 1,5 , and 10 percent level, respectively.

To further investigate this rather unexpected empirical finding, we control for gender gap in higher education rather than adult higher education in total. The variable is expected to capture the effects on household saving rate of a change in higher education attainment by female relative to male adults, which adult higher education in total might fail to account for. Table 3 shows the regression results with the variable gender gap in higher education in place of total adult higher education. Most empirical findings in Table 3 are consistent with those in Table 2 except higher education, household debt, and household net worth. First, the estimated coefficients of gender gap in higher education are negative and statistically significant at 10 percent level across the three models. Together with a positive impact on household saving rate of gender gap in employment, it may be inferred that a gain in the female attainment of higher education relative to male adults is an added contribution to an increase in household income and thus household saving rate. In addition, the variables, household debt and household net worth, are now statistically significant predictor of household saving rate.

\section{Conclusion}

In this study we examined factors that are conducive to a change in household saving rate. In addition to traditional determinants of household saving such as life expectancy and preferential income tax rates for households with children, we have identified among the 36 
OECD member countries that household saving rate is sensitive to changes in socio-economic and -demographic conditions that promote the human capital value of female labor force and thus female employment opportunities. Our empirical models explicitly controlled for gender gap in higher education as well as in employment. Our key finding is that the narrower is the gap between genders in higher education attainment and employment, the great is the household saving rate. Our empirical findings also suggest that giving childbirth at an old age is negatively affecting the household saving rate.

The regression results of this study should be interpreted with caution in that some of the explanatory variables are measured at the individual or household level of a country. Explaining heterogeneous household saving decisions using the mean value of variables leaves out many important aspects of household saving decisions. It is most pressing that more micro-level data become available, enabling future research to capture the details of individual-level saving decision processes.

\section{References}

Ameriks, J., Caplin, A., Laufer, S., \& Van Nieuwerburgh, S. (2011). The joy of giving or assisted living? Using strategic surveys to separate public care aversion from bequest motives. The Journal of Finance, 66(2), 519-561. https://doi.org/10.1111/j.1540-6261.2010.01641.x

Ameriks, J., \& Zeldes, S. P. (2004). How do household portfolio shares vary with age? (Working paper). Columbia University.

Ando, A., \& Modigliani, F. (1963). The 'life-cycle' hypothesis of saving: aggregate implication and tests. American Economic Review, 53, 55-84.

Athukorala, P., \& Sen, K. (2001). The determinants of private saving in India. Research School of Pacific and Asian Studies, The Australian National University, Canberra.

Athukorala, P., \& Tsai, P. (2003). Determinants of household saving in Taiwan: growth, demography and public policy. Journal of Development Studies, 39(5), 65-88.

https://doi.org/10.1080/00220380412331333149

Bainardi, D., Magnani, M., \& Menegatti, M. (2020). The theory of precautionary saving: an overview of recent developments. Review of Economics of the Household, 18, 513-542. https://doi.org/10.1007/s11150-019-09460-3

Banks, J., Blundell, R., \& Tanner, S. (1998). Is there a retirement-savings puzzle? American Economic Review, 88(4), 769-788.

Barro, R. J. (1974). Are government bonds net wealth? Journal of Political Economy, 82(6), 1095-1117. https://doi.org/10.1086/260266

Beckmann, E., Hake, M., \& Urvova, J. (2013). Determinants of households' savings in Central, Eastern and Southeastern Europe. Focus on European Economic Integration, Q3, 8-29.

Browning, M., \& Crossley, T. F. (2001). The life-cycle model of consumption and saving, Journal of Economic Perspectives, 15(3), 3-22. https://doi.org/10.1257/jep.15.3.3 


\section{Al Macrothink}

Business and Economic Research ISSN 2162-4860 2021, Vol. 11, No. 2

Cagetti, M. (2000). Wealth accumulation over the life cycle and precautionary savings (Mimeo). University of Virginia.

Carroll, C. D. (1992). The buffer-stock theory of saving: Some macroeconomic evidence. Brookings Papers on Economic Activity, 2, 61-135. https://doi.org/10.2307/2534582

Carroll, C. D., \& Samwick, A. (1997). The nature of precautionary wealth. Journal of Monetary Economics, 40(1), 41-71. https://doi.org/10.1016/S0304-3932(97)00036-6

Carroll, C. D., Dynan, K., \& Krane, S. (2003). Unemployment risk and precautionary wealth: Evidence from households' balance sheets. Review of Economics and Statistics, 85, 586-604. https://doi.org/10.1162/003465303322369740

Case, K. E., Quigley, J. M., \& Shiller, R. J. (2005). Comparing wealth effects: The stock market versus the housing market. Advances in Macroeconomics, 5, 1-34.

https://doi.org/10.2202/1534-6013.1235

De Nardi, M., French, E., \& Jones, J. B. (2015). Savings after retirement: A survey (No. W21268). National Bureau of Economic Research. https://doi.org/10.3386/w21268

Diamond, P. A., \& Hausman, J. A. (1984). Individual retirement and saving behavior. Journal of Public Economics, 23, 81-114. https://doi.org/10.1016/0047-2727(84)90068-9

Durand, J. D. (1979). The labor force in economic development: A comparison of international census data 1946-1966. Economic Review, 30(2), 185-187.

Dvornak, N., \& Kohler, M. (2007). Housing wealth, stock market wealth and consumption: A panel analysis for Australia. Economic Record, 83, 117-130.

https://doi.org/10.1111/j.1475-4932.2007.00388.x

Dynan, K. E., Skinner, J., \& Zeldes, S. P. (2002). The importance of bequests and life-cycle saving in capital accumulation: A new answer. American Economic Review, 92(2), 274-278. https://doi.org/10.1257/000282802320189393

Feldstein, M. S. (1974). Social security, induced retirement, and aggregate capital accumulation. Journal of Political Economy, 82(5), 905-926. https://doi.org/10.1086/260246

Feldstein, M. S. (1982). Social security and private saving: Reply. Journal of Political Economy, 90(3), 630-641. https://doi.org/10.1086/261078

Friedman, M. (1957). A theory of the consumption function. Princeton University Press, New Jersey, U.S.A. https://doi.org/10.1515/9780691188485

Gourinchas, P. O., \& Parker, J. A. (2002). Consumption over the life cycle. Econometrica, 70, 47-89. https://doi.org/10.1111/1468-0262.00269

Harrigan, F. (1996). Saving transitions in Southeast Asia. Asian Development Bank, Manila.

Harris, M. H., Loundes, J., \& Webster, E. (2002). Determinants of household saving in Australia. Economic Record, 78(241), 129-247. https://doi.org/10.1111/1475-4932.00024 
Hubbard, R. G. (1986). Pension wealth and individual saving. Journal of Money, Credit, and Banking, 18, 167-178. https://doi.org/10.2307/1992200

Hubbard, R. G., Skinner, J., \& Zeldes, S. (1995). Precautionary saving and social insurance. Journal of Political Economy, 103(2), 360-399. https://doi.org/10.1086/261987

Jayachandran, S. (2020). Social norms as a barrier to women's employment in developing countries. National Bureau of Economic Research Working Paper Series (W27449), National Bureau of Economic Research, Cambridge, MA. https://doi.org/10.3386/w27449

Joo, S., \& Grable, J. E. (2000). A retirement investment and saving decision model: influencing factors and outcomes. Consumer Interest Annual, 46, 43-48.

Kennickell, A., \& Lusardi, A. (2004). Disentangling the importance of the precautionary saving mode. National Bureau of Economic Research Working Paper Series (W10888), National Bureau of Economic Research, Cambridge, MA. https://doi.org/10.3386/w10888

Kim, M. H. (2010). The determinants of personal saving in the U.S. The Journal of Applied Business Research, 26(5), 35-44. https://doi.org/10.19030/jabr.v26i5.317

Kimball, M. S. (1992). Precautionary motives for holding assets. Econometrica, 61, 589-611. https://doi.org/10.2307/2951719

Leland, H. (1968). Saving and uncertainty: the precautionary demand for saving. Quarterly Journal of Economics, 82, 465-473. https://doi.org/10.2307/1879518

Lusardi, A. (1997). Precautionary saving and subjective earnings variance. Economics Letters, 57, 319-326. https://doi.org/10.1016/S0165-1765(97)00239-5

Lusardi, A. (1998). On the importance of the precautionary saving motive. American Economic Review Papers and Proceedings, 88, 449-453.

Magnani, M. (2017). A new interpretation of the condition for precautionary saving in the presence of an interest-rate risk. Journal of Economics, 120, 79-87.

https://doi.org/10.1007/s00712-016-0496-2

Masson, P. R., Bayoumi, T., \& Samiei, H. (1998). International evidence on the determinants of private saving. The World Bank Economic Review, 12(3), 483-501.

https://doi.org/10.1093/wber/12.3.483

Menegatti, M. (2007). A new interpretation for the precautionary saving motive: a note, Journal of Economics, 92, 275-280. https://doi.org/10.1007/s00712-007-0279-x

Mulligan, R. F. (2014). The central fallacy of Keynesian economics. Quarterly Journal of Austrian Economics, 17(3), 338-364.

Nocetti, D. C., \& Smith, W. T. (2011). Precautionary saving and endogenous labor supply with and without intertemporal expected utility. Journal of Money, Credit and Banking, 43, 1475-1504. https://doi.org/10.1111/j.1538-4616.2011.00432.x

Ouliaris, S., \& Rochon, C. (2018). The U.S. personal saving rate. IMF Working Paper No. 
18/128. https://doi.org/10.5089/9781484357941.001

Ozcan, K. M., Gunay, A., \& Ertac, S. (2003). Determinants of private savings behaviour in Turkey. Applied Economics, 35(12), 1405-1416.

https://doi.org/10.1080/0003684032000100373

Pootrakool, K., Ariyapruchya, K., \& Sodsrichai, T. (2005). Long-term saving in Thailand. Bank of Thailand, Bangkok.

Poterba, J. M. (Ed.). (1994). International comparison of household saving. Chicago, Ill.: University of Chicago Press. https://doi.org/10.7208/chicago/9780226676289.001.0001

Poterba, J. M. (1996). Personal saving behavior and retirement income modeling: A research assessment. In E. A. Hanushek \& N. L. Maritato (Eds.), Assessing Knowledge of Retirement Behavior. National Academy Press.

Poterba, J. M., \& Wise, D. A. (1996). Individual financial decisions in retirement saving plan and the provision of resources for retirement. National Bureau of Economic Research Working Paper (W5762), National Bureau of Economic Research, Cambridge, MA. https://doi.org/10.3386/w5762

Roche, H., Tompaidis, S., \& Yang, C. (2013). Why does junior put all his eggs in one basket? A potential explanation for holding concentrated portfolios. Journal of Financial Economics, 109(3), 775-796. https://doi.org/10.1016/j.jfineco.2013.03.016

Swasdpeera, P., \& Pandey, I. M. (2012). Determinants of personal saving: a study of salaried individuals in Thailand. Afro-Asian Journal of Finance and Accounting, 3(1), 34-68. https://doi.org/10.1504/AAJFA.2012.046347

Skinner, J. (1988). Risky income, life cycle consumption and precautionary saving. Journal of Monetary Economics, 22, 237-255. https://doi.org/10.1016/0304-3932(88)90021-9

Summers, L. (2016), Secular stagnation and monetary policy. Federal Reserve Bank of St. Louis Review, 98(2), 93-110. https://doi.org/10.20955/r.2016.93-110

Vergara, M. (2017). Precautionary saving: a taxonomy of prudence. Economics Letters, 150, 18-20. https://doi.org/10.1016/j.econlet.2016.10.029

Unny, C. J. (2002). Determinants of saving of rural households in Kerala. Department of Economics, Christ College, Kerala.

Weil, P. (1993). Precautionary savings and the permanent income hypothesis. Review of Economic Studies, 60, 367-383. https://doi.org/10.2307/2298062

\section{Copyright Disclaimer}

Copyright for this article is retained by the author(s), with first publication rights granted to the journal.

This is an open-access article distributed under the terms and conditions of the Creative Commons Attribution license (http://creativecommons.org/licenses/by/4.0/). 